\title{
Corrigendum to "Inhibitory Effect of a French Maritime Pine Bark Extract-Based Nutritional Supplement on TNF- $\alpha$-Induced Inflammation and Oxidative Stress in Human Coronary Artery Endothelial Cells"
}

\author{
Kristine C. Y. McGrath $\mathbb{D}^{1},{ }^{1}$ Sumudu V. S. Gangoda, ${ }^{2}$ Xiao-Hong Li $\mathbb{1},{ }^{1,3}$ \\ Lucinda S. McRobb, ${ }^{4}$ and Alison K. Heather ${ }^{5}$ \\ ${ }^{1}$ Molecular Biosciences Team, School of Life Sciences, University of Technology Sydney, Broadway, NSW, Australia \\ ${ }^{2}$ Department of Biomedical Sciences, Faculty of Medicine and Health Sciences, Macquarie University, Sydney, Australia \\ ${ }^{3}$ Department of Endocrinology, Dezhou People's Hospital, Shandong, China \\ ${ }^{4}$ Department of Clinical Medicine, Macquarie University, Sydney, NSW 2109, Australia \\ ${ }^{5}$ Department of Physiology, Otago School of Medical Sciences, University of Otago, Dunedin, New Zealand
}

Correspondence should be addressed to Kristine C. Y. McGrath; kristine.mcgrath@uts.edu.au

Received 7 August 2018; Accepted 9 August 2018; Published 5 November 2018

Copyright (C) 2018 Kristine C. Y. McGrath et al. This is an open access article distributed under the Creative Commons Attribution License, which permits unrestricted use, distribution, and reproduction in any medium, provided the original work is properly cited.

In the article titled "Inhibitory Effect of a French Maritime Pine Bark Extract-Based Nutritional Supplement on TNF$\alpha$-Induced Inflammation and Oxidative Stress in Human Coronary Artery Endothelial Cells" [1], Dr. Sumudu V. S. Gangoda was missing from the authors' list. Dr. Gangoda contributed to the data acquisition. The corrected authors' list is shown above.

\section{References}

[1] K. C. Y. McGrath, X.-H. Li, L. S. McRobb, and A. K. Heather, "Inhibitory effect of a french maritime pine bark extract-based nutritional supplement on TNF- $\alpha$-induced inflammation and oxidative stress in human coronary artery endothelial cells," Evidence-Based Complementary and Alternative Medicine, vol. 2015, Article ID 260530, 7 pages, 2015. 


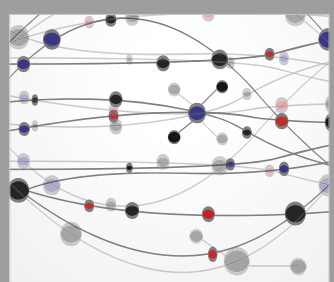

The Scientific World Journal
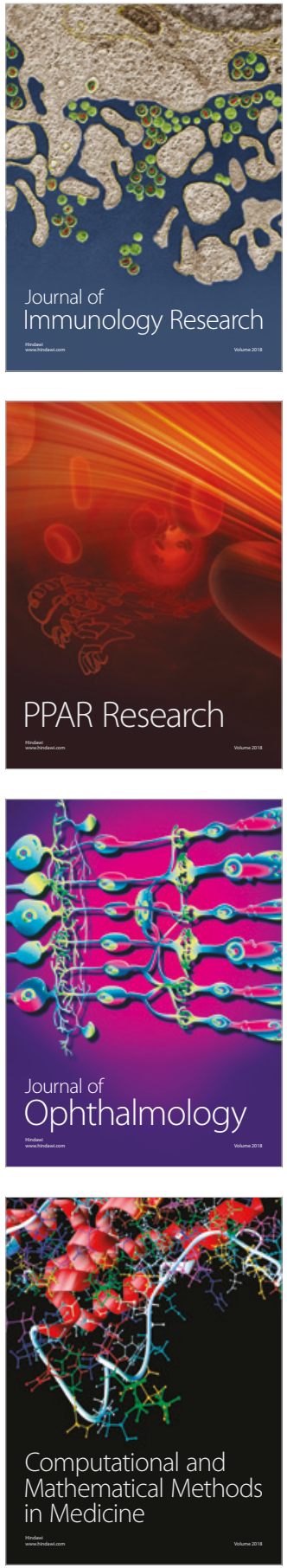

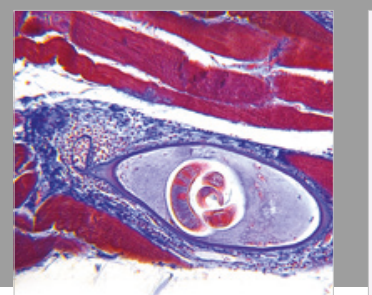

Gastroenterology Research and Practice

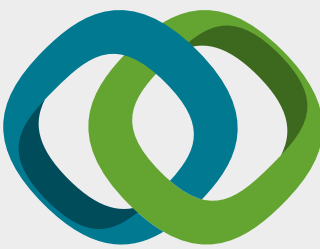

\section{Hindawi}

Submit your manuscripts at

www.hindawi.com
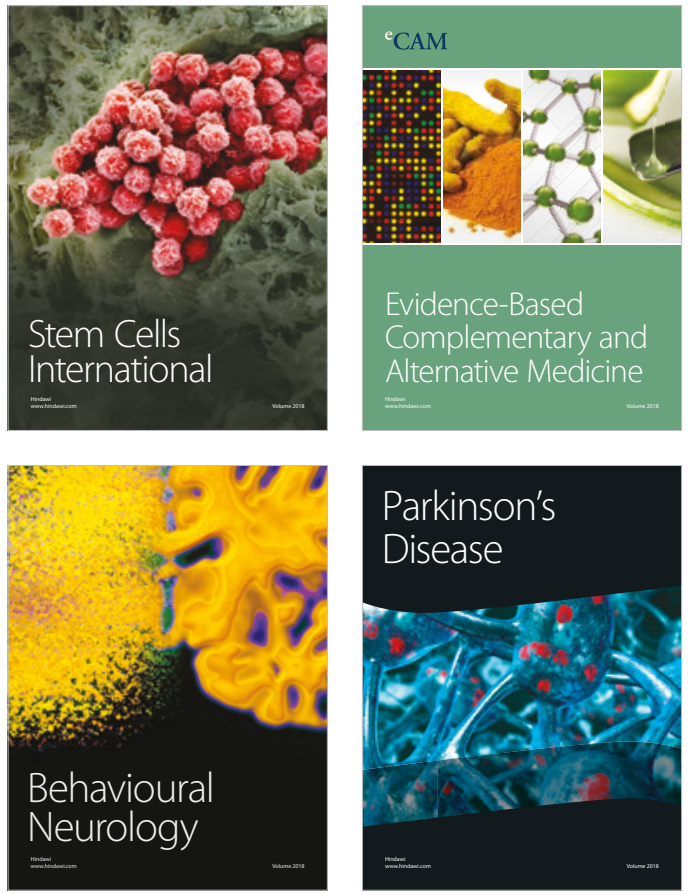

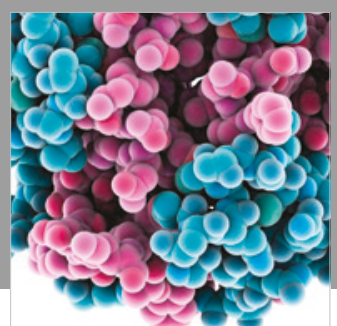

ournal of

Diabetes Research

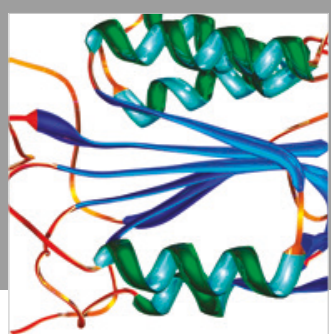

Disease Markers
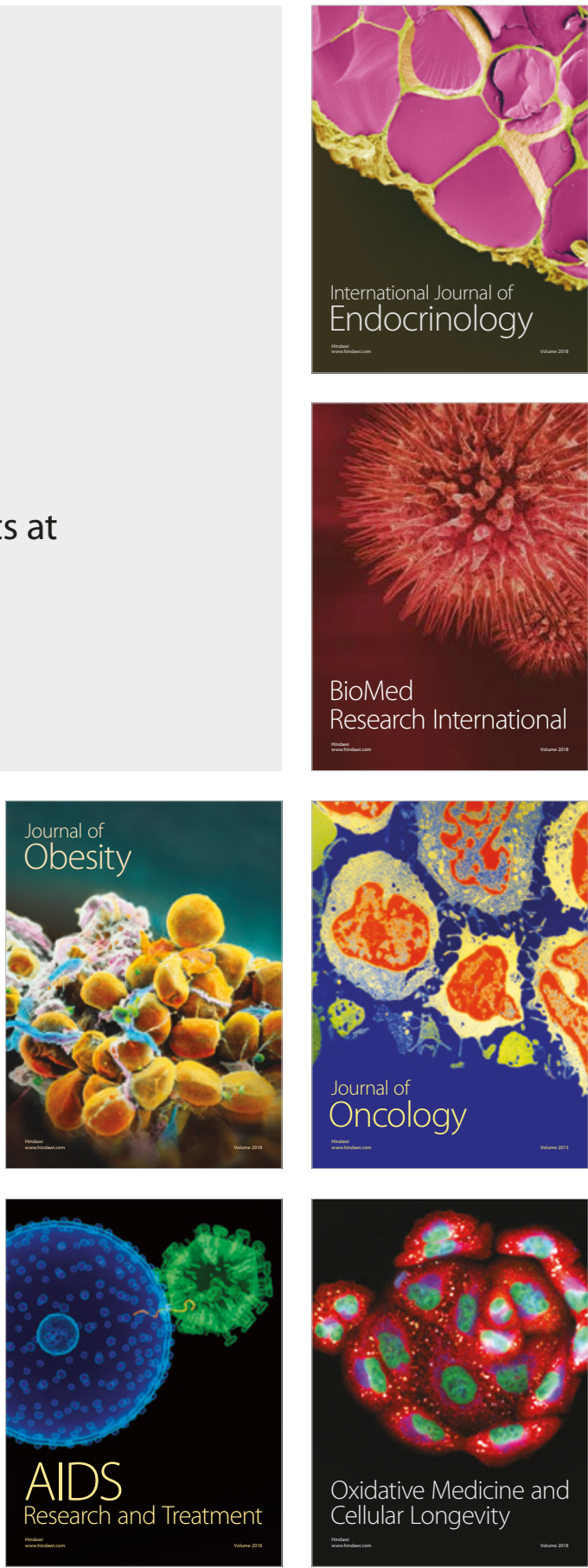